\title{
Cavernous sinus syndrome due to rhino-orbital-cerebral mucormycosis*
}

\author{
Síndrome do seio cavernoso secundária a mucormicose rino-orbitocerebral

\begin{abstract}
Vagner Moysés Vilela ${ }^{1}$, Hélder de Castro Marques ${ }^{2}$, Rodolfo Elias Diniz da Silva Carvalho ${ }^{1}$, Erika Zavelinske ${ }^{1}$, André Geraldo da Silva Duque ${ }^{1}$, Bruno Landim Dutra ${ }^{1}$
\end{abstract}

\begin{abstract}
The present report describes the case of a 43-year-old diabetic patient with facial pain, protruding eyes, nasal congestion and decreased right vision (involvement of the ipsilateral cranial nerves III, IV and V). Computed tomography showed diffuse sinusitis at right, cribriform plate erosion and presence of a hypodense collection in the frontal lobe with peripheral enhancement. Magnetic resonance imaging confirmed the presence of a cerebral abscess. Samples were collected from the lesion, confirming hyphae compatible with mucormycosis.
\end{abstract}

Keywords: Syndrome; Cavernous sinus; Mucormycosis.

Resumo Neste estudo relata-se um caso de paciente do sexo masculino, 43 anos de idade, diabético, apresentando dor facial, protrusão ocular, congestão nasal e redução visual à direita (acometimento do III, IV e V nervos cranianos ipsilaterais). A tomografia computadorizada mostrou sinusopatia difusa à direita, erosões da lâmina crivosa e coleção hipodensa no lobo frontal, com realce periférico. A ressonância magnética confirmou abscesso cerebral. Foram coletadas amostras da lesão, confirmando-se hifas compatíveis com mucormicose.

Unitermos: Síndrome; Seio cavernoso; Mucormicose.

Vilela VM, Marques HC, Carvalho REDS, Zavelinske E, Duque AGS, Dutra BL. Cavernous sinus syndrome due to rhino-orbital-cerebral mucormycosis. Radiol Bras. 2013 Mai/Jun;46(3):187-189.

\section{INTRODUCTION}

The imaging evaluation of the rhino-orbital region has been object of a recent range of publications in the Brazilian radiological literature ${ }^{(1-6)}$.

Cavernous sinus syndrome affects such sinus which involves the "cavernous portion" of the internal carotid artery, the III, IV and VI cranial nerves, in their course towards the orbital apex, and the V1 and V2 branches of the $\mathrm{V}$ nerve.

Mucormycosis is a severe fungal infection which frequently progresses to death ${ }^{(7)}$, caused by the Mucorales order of fungi.

\section{CASE REPORT}

A male, 43-year-old patient with irregularly treated diabetes, presenting rightsided facial pain with ipsilateral proptosis,

* Study developed at Hospital Universitário da Universidade Federal de Juiz de Fora (HU-UFJF), Juiz de Fora, MG, Brazil.

1. MDs, Residents at Unit of Radiology and Imaging Diagnosis, Hospital Universitário da Universidade Federal de Juiz de Fora (HU-UFJF), Juiz de Fora, MG, Brazil.

2. MD, Radiologist, Unit of Radiology and Imaging Diagnosis, Hospital Universitário da Universidade Federal de Juiz de Fora (HU-UFJF) and Grupo Alliar, Juiz de Fora, MG, Brazil.

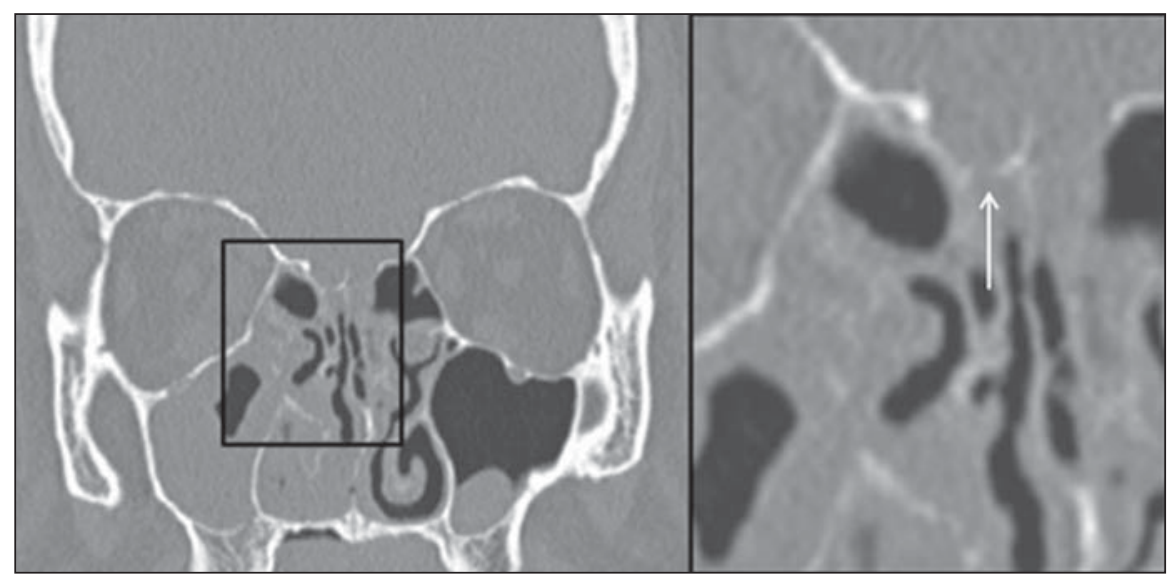

Figure 1. Bone window computed tomography with coronal reconstruction of paranasal sinuses. Cribriform plate erosion is more clearly demonstrated on the magnified view (arrow).

nasal congestion and decreased visual acuity. At clinical examination, the patient presented signs of involvement of the cranial nerves III and IV, V1 and V2 trigeminal branches at right and ipsilateral palatal ulcer.

Mailing Address: Dr. Vagner Moysés Vilela. Rua Major Tito César, 55, Centro. Ubá, MG, Brazil, 36500-000. E-mail: vmoyses@gmail.com.

Received September 6, 2012. Accepted after revision February 15,2013
Paranasal sinuses computed tomography (Figure 1) showed diffuse sinusitis at right, cribriform plate erosion and presence of a hypodense collection in the frontal lobe with peripheral contrast uptake and without cleavage plane with the eroded cribriform plates.

Magnetic resonance imaging (Figure 2) confirmed the presence of a cerebral abscess adjacent to the cavernous sinuses. Such sinuses, on their turn, were asym- 


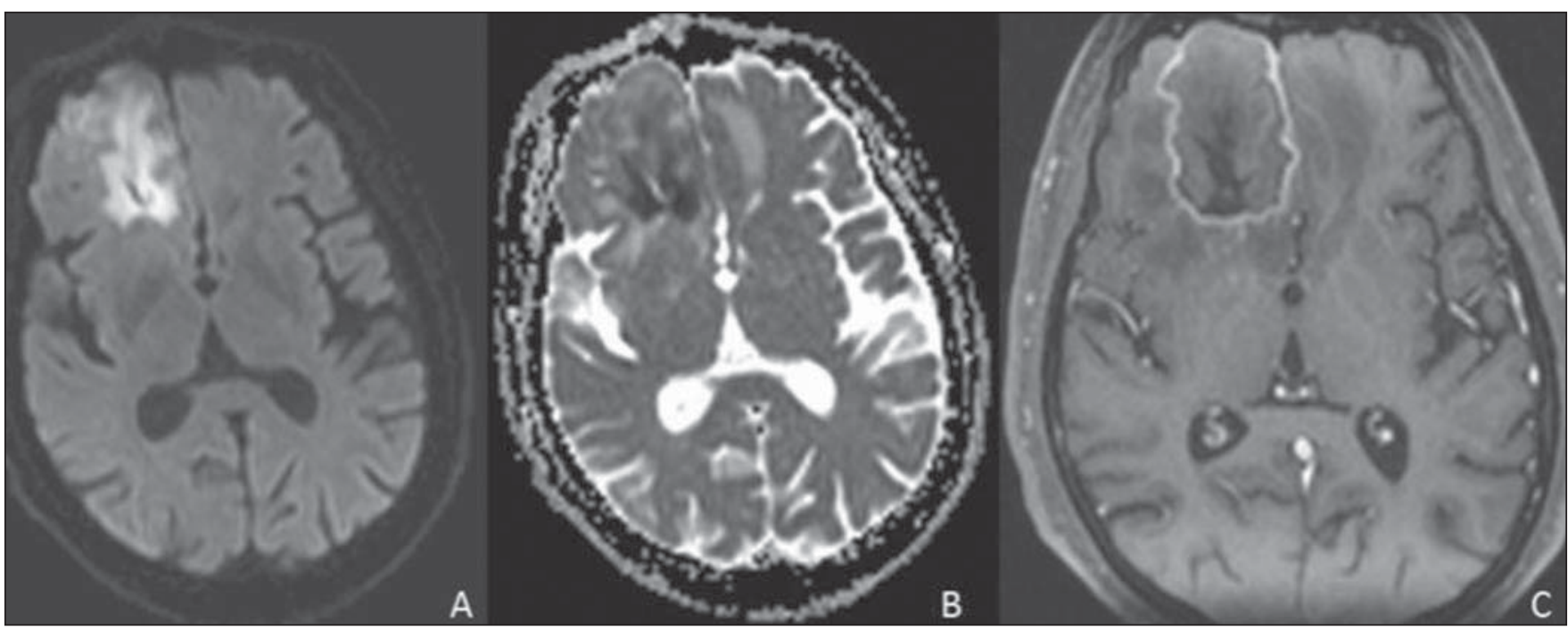

Figure 2. Axial, diffusion-weighted magnetic resonance imaging (A) demonstrating true restriction confirmed by ADC mapping (B). Gadolinium enhanced T1weighted image demonstrating heterogeneous and predominantly peripheral enhancement of the cerebral lesion (C).

metrical (Figure 3). Additionally rightsided proptosis was observed, with inflammatory tissue invading the orbital apex and the ipsilateral medial rectus muscle. Also, this method revealed the "black turbinate sign" which, in spite of being uncommon, considerably reinforced the hypothesis of mucormycosis (Figure 4).

Samples were collected from the palatal ulcer, paranasal sinuses secretion and from the cerebral abscess. The latter were prepared for histopathological analysis and culture, confirming the presence of aseptate or poorly septate hyphae compatible with the diagnosis of mucormycosis.

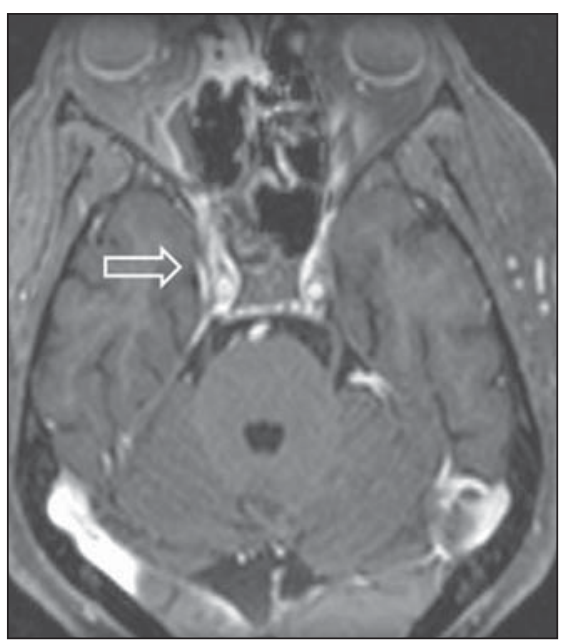

Figure 3. Contrast-enhanced axial magnetic resonance imaging T1-weighted sequence demonstrating asymmetrical uptake by the cavernous sinuses (arrow).
With basis on the biopsy results, treatment with liposomal amphotericin B was initiated and a combined neuro-otolaryngological intervention for necrosis debridement and abscess drainage was scheduled.

After a long hospital stay, the patient was discharged and remains under followup on an outpatient basis.

\section{DISCUSSION}

Most commonly, cavernous sinus syndrome is caused by inflammatory processes
(Tolosa-Hunt syndrome) followed by tumors, aneurysms, carotid cavernous fistulae and, less frequently, thrombophlebitis. Mucormycosis must be differentiated from other fungal rhinosinusites such as aspergillosis, but always keeping in mind that bacterial sinusites may also present cerebral abscess as a complication, particularly in children $^{(8)}$.

Computed tomography reveals signs of chronic sinusitis with opacification and mucosal thickening of such structures, as well as bone destruction and extension of

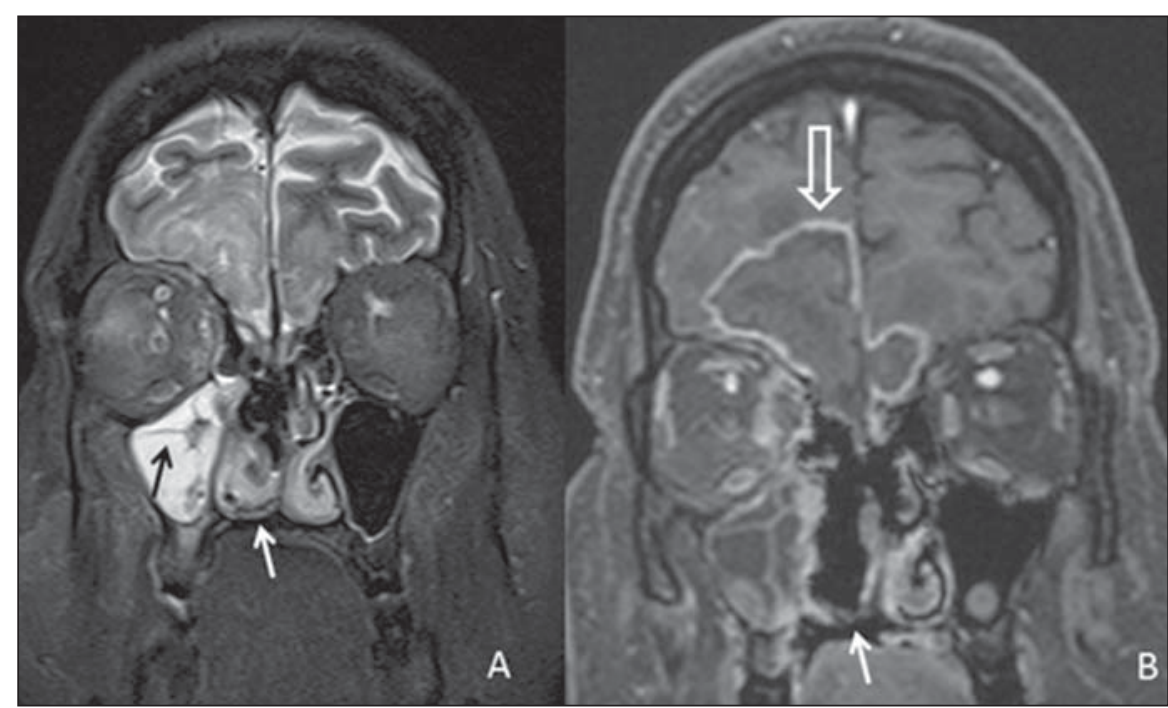

Figure 4. Coronal, T2-weighted section (A) and contrast-enhanced T1-weighted section (B) demonstrating diffuse sinusitis at right and hyposignal from the paranasal sinuses mucosa, most clearly seen on the maxillary sinus (black arrow), characterizing the mucosal impregnation by manganese in fungal infections, besides the "black turbinate sign" (white arrows) and demonstration of the frontal abscess on other plane (white hollow arrow). 
the inflammatory process to the intracranial compartment.

Magnetic resonance imaging is highly sensitive in the diagnosis of rhinocerebral mucormycosis. The paranasal sinuses involvement plays a decisive role specifically in the diagnosis of this condition characterized by the "black turbinate sign" which represents the angioinvasive nature of the lesion, defined by hyposignal on $\mathrm{T} 2$ weighted sequences and by the absence of mucosal enhancement of the turbinates consequential to the typical dry gangrene, allowing a reliable differentiation from other infectious rhinosinusites ${ }^{(9)}$. The cerebral damage occurs in the form of abscesses and infarcts with their habitual characteristics. The conclusive diagnosis depends on direct and histopathological smears analysis and on biopsies of necrotic material ${ }^{(\mathbf{1 0})}$.
In the suspicion of acute invasive fungal rhinosinusitis (mucormycosis), the treatment must be rapidly and aggressively started, with surgical procedure for removal of areas of necrosis in the nasal mucosa and utilization of intravenous systemic antifungal agents. Even so the mortality and morbidity rate is high $^{(\mathbf{1 0 - 1 2})}$.

\section{REFERENCES}

1. Aburjeli BOM, Ávila AFA, Diniz RLFC, et al. Concha nasal média secundária: relato de caso. Radiol Bras. 2012;45:351-2.

2. Niemeyer B, Bahia PRV, Oliveira ALVSM, et al Síndrome do granuloma letal da linha média: um dilema diagnóstico. Radiol Bras. 2012;45:353-5.

3. Gonçalves FG, Jovem CL, Moura LO. Tomografia computadorizada das células etmoidais intra e extramurais: ensaio iconográfico. Radiol Bras. 2011;44:321-6.

4. Reis F, Iyeyasu JN, Altemani AM, et al. Tumor de células granulares acometendo a órbita em uma criança. Radiol Bras. 2011;44:331-2.
5. Miranda CMNR, Maranhão CPM, Arraes FMNR, et al. Variações anatômicas das cavidades paranasais à tomografia computadorizada multislice: o que procurar? Radiol Bras. 2011;44:256-62.

6. Agnollitto PM, Nogueira-Barbosa MH. Síndrome de Gardner [Qual o seu diagnóstico?]. Radiol Bras. 2012;45(4):xi-xii.

7. Yohai RA, Bullock JD, Aziz AA, et al. Survival factors in rhino-orbital-cerebral mucormycosis. Surv Ophthalmol. 1994;39:3-22.

8. Garcia-Covarrubias L, Bartlett R, Barratt DM, et al. Rhino-orbitocerebral mucormycosis attributable to Apophysomyces elegans in an immunocompetent individual: case report and review of the literature. J Trauma. 2001;50:353-7.

9. Safder S, Carpenter JS, Roberts TD, et al. The "black turbinate" sign: an early MR imaging finding of nasal mucormycosis. AJNR Am J Neuroradiol. 2010;31:771-4.

10. Prabhu RM, Patel R. Mucormycosis and ento- 